\title{
Shifting Discourses in Social Sciences: Nexus of Knowledge and Power
}

\author{
Sivapalan Selvadurai ${ }^{1}$, Er Ah Choy ${ }^{1}$, Marlyna $\operatorname{Maros}^{1} \&$ Kamarulnizam Abdullah $^{1}$ \\ ${ }^{1}$ Faculty of Social Sciences and Humanities, Universiti Kebangsaan Malaysia, Bangi, Malaysia \\ Correspondence: Er Ah Choy, Faculty of Social Sciences and Humanities, Universiti Kebangsaan Malaysia, \\ 43600 Bangi, Malaysia. Tel: 60-3-8921-3945. E-mail: erahchoy@yahoo.com
}

Received: June 1, 2012 Accepted: March 22, 2013 Online Published: June 1, 2013

doi:10.5539/ass.v9n7p97 URL: http://dx.doi.org/10.5539/ass.v9n7p97

\begin{abstract}
Developing societies have often relied on Western or Eurocentric knowledge as a consequence of colonization process, intellectual imperialism, as well as experiences of the forces of modernization and its dependencies, as well as globalization rhetoric. The basic premise of this article is that all civilizations have potential sources of social science theorizing. This article explicates the general development of social sciences discourses in the West and response from the developing societies in particular. Specifically the article attempts to elaborate on the impasse in social science as it relates to domination of Eurocentric knowledge and the marginalization of local knowledge. In framing this article, insights on captive mind by Alatas and the notion of modern power by Foucault are utilized. Our approach to power and knowledge involves a multi-scalar analysis of the functioning of power relations that impinged on the social science discipline as experienced in the developing societies. Contestations from within the Western realm as well as developing societies appear to provide a remedy to the contemporary situation, but somewhat at a slow pace and operating in the margins. The relevance of adapting to local context and the institutional capacity for self-empowerment in localizing knowledge is a necessary path that developing societies should take.
\end{abstract}

Keywords: social sciences, captive mind, modern power, localization of knowledge

\section{Introduction}

Since the inception of modern science in the West, its orientation has dominated the intellectual landscape of the world, both in the natural science and social science disciplines. To a large extent much of the Western discourse of social science knowledge has been viewed and taken for granted as universal knowledge. However recent developments within the social science fraternity have witnessed changes not only within the Western mainstream discourse but also outside the mainstream. Within the Western epistemology the shift from positivist to post-positivist critical school has seen the proliferation of approaches and methodologies contesting the stability of its conventional paradigm. Amidst this bandwagon effect within the Western context, movements from outside namely non-Western alternative discourse have appeared to further pose challenges to the dominance of Western discourse in social science disciplines. As such the key questions that this article explores are: what are the contexts and reasons for the state of dominance of Western knowledge in the developing countries? And what are the responses from the margins towards remedying this situation?

In framing this article, the relationship between knowledge and power, and insights on captive mind by Syed Hussein Alatas (1971) and the notion of modern power by Foucault $(1997,1971)$ are utilized. This article argues for a shift from a partial version of globalization of knowledge (read as Western universal claims to knowledge) of social science to a state of localization of knowledge (read as local knowledge, indigenous knowledge, decolonized knowledge etc.). This is based on the basic premise of this article that all civilizations (read countries or local areas) have potential sources of social science theorizing that can provide alternative discourses as local knowledge relevant to their context (Sinha, 1997). As such with the addition and complementary role of localization of knowledge one can fulfill the need for a comprehensive global knowledge. Currently the popular version of universal Western knowledge is wrongly promoted as global knowledge and only reflects partially the global scope (i.e. Western context only), due to the unequal power relations in knowledge creation.

This article begins with the issue of social science impasse in knowledge domination, followed by the framework 
of knowledge and power, the state of affairs of social sciences discourses in the developing societies, and finally, response from the margin.

\section{The Social Science Impasse}

This section attempts to elaborate on the impasse in social science as it relates to domination of Eurocentric knowledge and the marginalization of local knowledge. During the post-colonial condition, the rubric of modernization and capitalist development path has brought about pervasive social change processes that developing societies have experienced. These processes have brought about many problems, as well as provide opportunities. In order to understand the problems that beset the developing societies, one can find the reliance of developing countries on Western knowledge where such discourses were prevalent in the social scientific community of these developed societies. Besides that, social science was institutionalized in the West and became available to the wider world community at large. Developing societies in post-colonial conditions were also preoccupied in survival issues and fulfilling mundane basic needs. Inevitably, as a consequence of this situation, developing societies were basically emulating and copying Western knowledge by way of verifying theories and concepts in social science literature, without much questioning or critically examining the assumptions and the underlying ideological framework.

There were discontent in the developing society's scientific community as to the inadequacy of social scientific concepts and its associated modernist discourse (Alatas, 1995). This impasse is not only at the level of understanding appropriate social scientific concepts but also appropriate development approaches suited to the developing society's context. What actually went wrong?

Theories and concepts from the West do not appear to meet or explain the state of affairs in the developing societies. The normative concerns of people in question are not addressed, instead presuppositions from the West does not cohere with the needs of the developing societies. The developing societies were still suffering and experiencing underdevelopment even though numerous concepts and theories have been promulgated. Questions arise as to whether it is simply because the domination of Western ideas as a consequence of the training acquired by local researchers, or simply lack of creative locals to venture into developing local knowledge and address local issues and formulate appropriate local social action. Another concern is the false belief that only Western concepts and theorizing are universal, and therefore ought to be tested and proven before theorizing is done. This was because the deductive convention that was prevalent in the academia then requires the coverage of literature which inevitably was dominated by the written tradition of the West. As a consequence the natural outcome of this process is the insidious citation of the literature from the West and the consolidation of the Western knowledge and further dominance of Western knowledge is reinforced. How can the developing societies overcome this impasse of the social scientific concepts and framework?

\section{Politics of Knowledge: Nexus of Knowledge and Power}

To understand the state of social science knowledge development in the developing societies, the relationship between knowledge and power is explicated. Knowledge is known to shape power as illustrated in the following quote:

Knowledge linked to power, not only assumes the authority of 'the truth' but has the power to make itself true. All knowledge, once applied in the real world, has effects, and in that sense at least, 'becomes true.' Knowledge, once used to regulate the conduct of others, entails constraint, regulation and the disciplining of practice. Thus, 'there is no power relation without the correlative constitution of a field of knowledge, nor any knowledge that does not presuppose and constitute at the same time, power relations'(Foucault, 1995: 27)

Since the developing societies are dependent on Western countries for knowledge transfer and imitation, this relationship is itself suggestive of the power of the Western countries over the developing societies, particularly in dealing with discourses relating to social science and technology. Foucault (1991) offered methodologies for investigating power and power relations by reexamining the 'foundations' of critical modern thought and the conditions through which modern societies operate. This way of investigation also enables analysts to examine the constitution of the subject in power relations (as cited in Popkewitz and Brennan 1997: 287). As a result developing countries were found to emulate Western and modernist thought without realizing the epistemological foundations underpinning some of the models. This has been Foucault's "contribution to recent social theory, providing both methodological and substantive challenges to the social sciences" (as cited in Popkewitz \& Brennan, 1997: 287)

However, what Foucault (1991) was trying to argue is not the hard power (i.e. sovereign power) that the Western 
colonizers have been able to subjugate the developing societies physically, but the soft power (i.e. modern power), in a more pervasive and subtle manner. According to Foucault (1980: 39) this modern power or commonly referred to as disciplinary power, operates in a capillary-like nature, where power "reaches into the very grain of individuals, touches their bodies and inserts itself into their actions and attitudes, their discourses, learning processes and everyday lives." Though subtle, this disciplinary power functions to control, i) with technologies of regulation and surveillance, ii) changing patterns of thought and behavior through techniques of training, iii) rational rather than ritual in orientation, and iv)tend to take place within specific institutions (Foucault, 1995: 27). The infiltration of this disciplinary power illustrates the role of core states or developed states, that even after the decolonization process they still have control over developing states in the realm of ideas and institutional practices. This domination of the subconscious is captured vividly by Syed Hussein Alatas $(1972,1974)$ in his concept of captive mind. Basically captive mind represents the extension of colonial mentality or categories by the recipient country in relation to the application of social sciences from the developed states or the West, without adaptation or critique of the adopted concepts and methodologies, suggesting the continued domination of Western ideas.

Syed Hussein Alatas's (1974) goal was to seek for an indigenous social science discourse that accounts for a socio-historical context, dismissing the imitation of Western concepts by indigenous scholars. Syed Hussein Alatas (1974) asserts that captive mind of the subject is not necessarily intentionally imposed by the colonial or Western discourse but the subjects (colonized or developing countries) themselves submit unconsciously, or are unaware of their own captivity. This idea in another sense coheres with the notion of cultural hegemony as espoused by Gramsci's notion of how domination and control are achieved by consent. Foucault uses the notion of governmentality to specify the complex tactics, procedures and apparatuses that dominant modern states used to control and influence the conduct of individuals by using truth, knowledge, and political economy, rather than force (Dean, 1999). Thus, the art of governing by nurturing voluntary compliance in subjects is achieved through modern or disciplinary power.

In fact Foucault's notion of modern disciplinary power can be extended as a dominant force through various processes of institutionalization and normalization within the political, economic, as well as cultural sphere. These processes have profound and long lasting effect in constraining alternative forms of discourse and knowledge amongst the developing countries. However Foucault is aware that dominance of knowledge can lead to contestations (Popkewitz \& Brennan, 1997). This suggests that the dominance of mainstream Western discourse of knowledge can lead to subjects seeking alternative discourse which can act as a destabilizing power of the dominant Western discourse. This counterforce provides hope for the insertion of localization of knowledge in the universal or global knowledge frontier. Thus, Foucault approach offers a better understanding of the social sciences contextual development of domination as well as its institutional capacity for self-empowerment.

\subsection{Localization of Knowledge as Empowering}

Localization of knowledge entails knowledge derived from social theorizing obtained within local historical and cultural context. This local sphere can be a locality or national sphere other than the mainstream or exogenous discourses and/or other forms of non-dependent knowledge systems. Syed Farid Alatas (2006: 81) has provided a broad view of alternative discourse (read as localization of knowledge) as encompassing indigenizing knowledge, decolonizing knowledge, endogenous intellectual creativity, and autonomous social science tradition. Syed Farid Alatas furthermore (2006: 81) refers to these alternatives as a "turn to philosophies, epistemologies, histories, and the arts other than those of the western tradition". Here we might add the civilizational wisdoms, local cultural values and precepts as possible sources of social theorizing in the process of localization of knowledge.

In order for the local knowledge to be part of the universal knowledge, it has to enact alternative (read local) social theorizing that provide a platform for the emergence of new knowledge, either challenging or contesting existing universal knowledge. Once the local knowledge has managed to destabilize existing universal knowledge, it will be able to gain power or empower as part of universal social science. Thus this knowledge-power matrix as espoused by Foucault can be both constraining and liberating to the developing societies (Popkewitz \& Brennan, 1997).

The hegemony of Western centric discourse through modern power (i.e. disciplinary power) experienced by developing societies has constrained further development of local or alternative discourse. But one can also posit the potential for local knowledge to liberate by acquisition of power by destabilizing the mainstream universal ideas from the gaze of the contemporary Western discourse. Thus the local knowledge can empower local capacity by providing agency for local action that can sustain long term development. 


\section{State of Affairs of Social Science Discourse}

Our approach to discuss the state of affairs in social science discourse utilizes the relationship of power and knowledge at different levels. This involves a multi-scalar analysis of the functioning of power relations that impinged on the social science discipline as experienced in the Western world and developing societies.

Social sciences and humanities have witnessed epistemological and ontological shifts in viewing their subject matter. Approaches in social sciences and humanities entail perspectives, theories and methodologies. These approaches encompass a better understanding in a subject matter. Early approaches characterized by positivist and objectivist views have been challenged by the contemporary subjectivist and constructivist approaches. These contemporary approaches have given greater emphasis to non-essentialist, anti-foundational, hermeneutic and agency viewpoints. Social sciences and humanities as a broad non-physical science discipline has experienced paradigm shift from modern to postmodern social theory, positivist to post-positivist views, and structuralist/realist theory to critical theory (Agger, 2006).

These broad shifts are also encountered in individual disciplines like sociology, geography, international relation, language and others. The shift from disciplinary to interdisciplinary approaches complements the area studies approach as these issues and phenomena are not single subject matters but entail multiple dimensions and disciplines (Kamarulnizam et al., 2010). Responding to problems and contemporary social transformations require widening opportunities for interdisciplinary approaches. Interdisciplinary approaches entail the integration of different disciplines into cohesive framework to tackle issues and social action. This is a challenge for the social sciences and humanities to bring in strength from diverse discipline into this framework. Most of these approaches has witnessed the adoption of Western epistemology and basically transported it to the developing societies.

The various disciplines in social science practiced in the developing societies have mainly borrowed knowledge and technologies from the Western discourse (read Euro-American or more specifically Anglo-Saxon tradition). This is because of various reasons : 1) most developing societies were either colonized directly or dependent on Western powers for political support, 2) even after post-independence era, the dominance of Western powers through varying international institutions has made possible the transfer of Western knowledge and education to the recipient developing societies, especially the Anglo-Saxon tradition dominance through the linguistic dominance of English language and the United Nation's agencies network, 3) modernization and industrialization strategies modeled after the Western capitalist path in developing countries required the acquisition of knowledge and education from the Western tradition, 4) the psychological state of low self-esteem amongst the academics, bureaucrats and business elites in developing societies resulted in their unconscious submission to the Western prowess in written tradition and technological edge.

The political-economic dependence of developing countries on the Western countries has consequently led to the dominance of the Western discourse on knowledge. The developing societies (read including Eastern societies) went on an emulation mode in copying in somewhat 'lock-stock-barrel' fashion the concepts, theories and methods adopted from the Western counterpart (Alatas, 2001) The lack of representation of developing scholars and their contribution to new knowledge amongst the scientific community (Backstrand, 2003) is not only frowned upon by Eastern and Southern counterpart, but also within the Western context as well. Critical feminist epistemology and social epistemology have tended to question the universalizing tendencies of scientific discourse of the West and the exclusion of local and subjugated knowledge as a consequence of linguistic and dominant power relations in the production of knowledge, some of which are often linked to market and state influence of the developed states. One can trace the root of the emulation models on modern thought of postcolonial state in most developing countries to the dominance of the pragmatic-analytic tradition of Anglo-Saxon tradition (particularly the nexus of US, Britain and Australia) in the global academic arena. It was only in the postwar period (i.e. WW II) that the West witnessed shifts in paradigm and integration of continental European historical and philosophical discourses. The offshoot of this integration is the nurturing of the Marxian critical tradition of Frankfurt School that led to establishment of critical theory. This critique coupled with the postmodernist movements has led to the reformation of social theory from within the West in the form of dialectic with the Anglo-Saxon dominance and its hegemonic role in academic discourse. What most developing countries like Malaysia have done was that they had played to the mainstream gallery by reinforcing the dominant and hegemonic structure of Western discourse. This state of affairs was portrayed as a condition of academic imperialism by Syed Naguib Al-Attas (1969). Syed Farid Alatas (2001) went further to spell out that the academic imperialism exist within a structure of academic dependency that links the Western and developing societies' scientists in an uneven and unequal manner, where even academic recognition (i.e. prestige value in journals) is sought from the West. 
The Anglo-Saxon hegemonic role in the academic discourse has also influenced the conceptual approach of security studies. The American and state centric notion of security proposed by Waltz (1979), Trager and Simonie (1973), and Louw (1977) tended to dominate the debates since the Cold War period. It was Al Mashat (1985) followed by Alagappa (1987) Ayoob (1987, 1995), Azar and Moon (1988), who brought in a new dimension of understanding security predicaments in developing countries. For years, westerns scholars failed to comprehend the basic security problems in developing countries were not about guns and bullets, but about bread and butter. Unemployment, access to a constant supply of food and fresh water, and basic health services among others, have finally been recognized by policy makers and scholars such as Kamarulnizam Abdullah (2012), Azizan Idris (2012), Makinda and Okumu (2007), Sity Daud and Zarina Othman (2005), Tan and Boutin (2001). These security challenges have been adapted as one of the central agenda for international security in the twenty-first century. Ironically, those issues were recognized as new security agenda cum human security issues by the United Nations only after the end of the Cold War.

Meanwhile, the social science academia in the developing world were enacting boundaries and distance from examining its own cultural-history, and even suspicious at its own status (Gergen et. al., 1996). This led to the domination of Western concepts, which were received with ease without adequate critique or adaptation for relevance, whilst indigenous concepts were not taken on board (Gergen et al., 1996). The marginalization of local knowledge is as a consequent of what was referred to as the subjects' captive mind by Syed Hussein Alatas (1972) earlier.

\section{Response from the Margin}

The response from the developing countries and scholars from the margins can be viewed from a macro level context, as well as contribution from individual key scholars and schools.

There are two counter-current streams of thought that is running through in the social science discourse in the developing world, namely at: i) the conceptual and theoretical level, and ii) at the practical and experiential level. Firstly, are the misgivings and apprehensions amongst the scholars from the developing world about the universal conception of social science promoted by Western academia and their market dominance through the Anglo-Saxon English linguistic dominance and also the willing submission of scholars from the developing world by embracing and emulating concepts from the partial West (i.e. Anglo-Saxon tradition) without localizing or indigenizing cultural context. Secondly, there is a reexamining of development and modernization of ideals and paradigms, in view of the devastation it has impacted upon local communities in the developing world, especially as a consequence of the unquestioned premise of capitalist development as the cornerstone of global development discourse (Ravichandran \& Sivapalan, 2010). This universalizing discourse though has brought material benefits in the short run, but has ramifications to local cultures and ecologies in the long run. The overwhelming marketization and commoditization processes of the developing economies has reenacted debates on the relevance and appropriateness of Western models to local contexts, which has led scholars exploring Eastern precepts or other alternatives as local or regional knowledge systems. This was found as necessary to harmonize with the local cultural and ecological environment.

Some of the key currents in the developing world are led by thinkers such as Franz Fanon, Syed Hussein Alatas, and Edward Said, as well as schools such as Subaltern school, area studies and comparative studies. Fanon's (1957) Black Skin White Masks was one of the early works in the developing world to examine the complicity of local or native with the colonized or dominant power. He posits the role of languages (i.e. French as medium of knowledge) in the Black's marginalization dilemma in Africa. The acquisition of foreign language over local language provides power and creates cultural difference and power imbalance. By embracing the foreign language as in the case of Algerian experience, Fanon suggests the local's complicity with the privileging of the foreign language and the eventual subordination of local or native language.

Concomitant with Fanon's discourse, the work of Syed Hussein Alatas $(1972,1974)$ in Southeast Asia provides a fervent ground for the Western counter force as captured in his notion of captive mind. Syed Farid Alatas provides a list of writers in South East Asia who were engaged in critical literature towards the Western dominance of ideas following the work of Syed Farid Alatas (2001), namely, Tham (1971), Chung (1989), Purushotam (1992, 1993), Sinha (1999), Wee (1988), Wee, Heyzer \& Kwa (1995) and Shamsul A. B. (1999). There were other undercurrents namely the work on Islamization of knowledge by Syed Naguib Al-Attas (1969) that attempts to ground the history of ideas in the Malay Archipelago.

Meanwhile Edward Said (1978) used the term Orientalism as the title of his book to describe a pervasive Western discourse of misrepresenting the East, shaped by the ideologies of the imperial West since modern era until now. Orientalism in this context refers to the Western discourse for its dominating, restructuring, and 
authoritative role over the Orient (namely East or developing societies). This coincides with the idea of intellectual imperialism of the West in representing others (namely East or developing societies) in inferior positions. In a follow up book on Culture and Imperialism, Said (1993) reasserts how imperialism manifests in both the material sphere as well as in the ideational realm. Thus the prevalence of colonizer or Western discourse and knowledge has profound effect on the beliefs, practices, and cultures of colonized nation and contemporary developing nations. Said (1993) emphasizes the link between imperialism and the human sciences, following the footsteps delineated by Foucault who had shown that the underlying foundations of truth of discourse were constructed and circulated by institutions of power.

Following Said's work, a group of Indian scholars led by Ranaji Guha (1982) has established the Subaltern Studies Group that attempt to provide a correction to the elite and official version of contemporary historical approach to the viewpoint of history from below that focuses on the masses version at the base levels of society. The Subaltern work together with Said's work launched the postcolonial approach to deal with the social science impasse from the colonial and Western perspective, especially the subjugated and captive minds of the academia, elites and bureaucrats in countries that had attained their independence. In 2012, Husen, Christensen, Hansen, Aharon, and Frid-Nielsen came out with a study on cultural domination in the Ghanaian educational system. They (2012: 2) argue that the country's colonial experience, economic dependence, top-down centralized decision making, and unequal access to educational system have been the key factors to a belief that "western values and English language are misrecognized as superior to local forms of knowledge"

Furthermore, the politics of knowledge, Kincheloe (2011: 387) argues, is the key to the Western manipulative strategy in spreading information. The West has profoundly manipulated the source of information and knowledge for ages. By controlling the source of information, the West was able to influence the international community's perception and attitude. Western media , for instance, created a belief that Saddam Hussein's regime possessed Weapons of Mass Destruction (WMD) or Israeli security has been threaten by the alleged possession of nuclear by Iran, though the authenticity of the information may be challenged. Yet, the advancement of information technology, Kincheloe (2011: 388) further argues has made it possible for people in the developing nations to validate information fed by the West.

The development of social science along disciplines utilizing social theory and humanities engagement in cultural theory has led to interest in area studies and interdisciplinary posture. Area studies had been developed in the West for international political and economic agenda (Anderson, 1984: 42-45). On the other hand, area studies in the developing nations have been developed to understand issues and phenomena in the neighboring countries and regions which share similar world view and culture. The involvement in comparative research in this similar area, will aid in enhancing our contextual knowledge. Area studies are essential as there are two different types of area studies; firstly, the Western propaganda area studies to fulfill political and economic agenda, and secondly, developing countries contextual studies for comparative purposes. These studies will enhance local knowledge, sharing of best practices and solutions as well as cross-cultural learning. Area studies have generated context specific knowledge and more recently have contributed towards a broader global agenda to capture a more nuanced network and interactional perspective (Kamarulnizam Abdullah et al. 2010). A case in point is the exportation of the Grameen Bank model of credit provision to several countries including the developed nations.

The cultural fabric and rich configuration of an amalgam of civilization in Southeast Asian context provide a rich resource for social theorizing. However lack of data in enacting local and historical wisdom prevails due to the prevalence of oral tradition as oppose to written tradition as in other regions. Also the presence of great civilizations and colonial occupation complicates the social and historical fabric. The fluidity of the influences of these civilizations on this part of the world, gives an impression that the varying influence would have provided wisdoms and knowledge that would have existed and sustained a cosmopolitan community.

Excavating this history requires some cross-cultural and linguistic exploration across multidiscipline such as archeological, historical, language, and oral history.

\subsection{Malaysia's Social Sciences Developments and Undertakings}

In the Malaysian front, Abdul Rahman Embong (2006) depicted that the development in social science in Malaysia was based on colonial thinking and knowledge systems. In the early 20th century, the establishment of University of Malaya (UM) in Singapore by Stamford Raffles focused on early social science disciplinary studies such as economics, sociology, history and geography, giving greater focus to material aspects of development issues. However, there were ideas that had emerged during the 19th century with Munshi Abdullah's contributing to the informal sphere of social and political front (Embong, 2006). These indigenous 
ideas and knowledge had indirectly contributed to the enhancement of local knowledge. During the post-independence era in the1960s, renewed debate on social science in Malaysia was led by Western and local scholars who were still influenced by colonial knowledge and methodologies. In 1974, a landmark seminar attempted to initiate indigenous ideas and confront future challenges amongst the local social scientists (Embong, 2006). This group of local scholars was primarily led by Marxist-trained and Marxist influenced anthropologists and sociologists who were involved in development issues. The 1980s witnessed the emergence of applied social science disciplines such as political science, communication, psychology, development studies, etc.

The evolution of studies in social science and humanities in the 1990s were still bounded by Western epistemology, resulting in dialectics of counter-currents. Debates on post-colonial knowledge polemics emerged in developing countries to overcome post-modern epistemic challenges posed in the West. Into the millennium, these currents are still ongoing. In the context of political and international studies, local debates are still tied up by Western conceptual and theoretical thinking dominated by either English or the American Schools. Similar trends were visible in the fields of psychology, sociology and human geography that saw the persistence of empiricism as a consequence of the dominance of the Anglo-Saxon colonial influence, at the expense of other alternative traditions. This situation can be attributed to the fact that for generations local scholars have been trained in a particular dominant Western tradition i.e. Anglo- Saxon influence. This was further exacerbated by the lack of interaction of regional scholars within the region in pursuing common regional and culturally contextual knowledge.

The question begets as to what extent the Malaysian experience, being a developing nation and still in the transition phase, can be transplanted into the other developing nations. This necessitates comparative studies with the other developing nations who are in similar phases of development and cultural practices. These cross-cultural learning experiences will further consolidate the area studies suited to developing countries research agenda. As such, future studies warrant in-depth research in this direction. As noted earlier, Southeast Asia provides a fertile ground for such cross-cultural understanding in enacting appropriate social action relevant to the experience of this region.

In response to this need, Malaysian research universities such as Universiti Kebangsaan Malaysia (UKM), Universiti Sains (Science) Malaysia (USM) and University of Malaya (UM) have embarked on collaborative efforts in the field of social sciences and humanities with the Southeast Asian countries through joint-research and bilateral seminar platforms., Universiti Kebangsaan Malaysia, for instance, has initiated such as SKIM conference (UKM with Universitas Pendjajaran, Bandung), SEBUMI conference (UKM with Universitas Indonesia), SERUMPUN (UKM with Universitas Hasanuddin), UKM-MAHIDOL University International College conference and others, besides attracting postgraduates research students from the region. Furthermore, the University of Malaya (UM) together with the National University of Singapore (NUS), due to their long historical linkages has also developed some collaboration through research and conferences. The belief of these collaborative efforts is that it would yield greater understanding and solutions attuned to the regional cultural context.

Besides that inter-disciplinary research on issues and phenomena warrant greater attention to multi-dimensional framework and contextualized in cultural-whole approaches so as to localize knowledge outcomes. The establishment of social science research centers in UKM for example has been tailored towards this end. Several research centers were put in place with specific focus namely among others: the Institute of The Malay World and Civilization (ATMA) - focusing on the Malay civilization and thoughts, and the Institute for Environment and Development (LESTARI), which has conducted various research on environment and development in Southeast Asia and Malaysia in particular. The Institute of Ethnic Studies (KITA), furthermore, has become a major regional referral center for ethic relations study. Other social science and multidisciplinary research centers in Malaysian universities include, among others, the Asia-Europe Institutes (UM), International Institute of Public Policy and Management or INPUMA (UM), Institute of China Studies (UM), Centre for Policy Research and International Studies (USM), and Women's Development Research Centre (USM). These research centers attempt to fill the gap in the existing knowledge systems that necessitate strategic as well as relevant deliberations to address national and local issues.

Future deliberations in Malaysian studies and wider regional studies should intensify intellectual discourse and debates at the conceptual level. Social sciences and humanities approaches should place more emphases on the cultural dynamics and the role of institutions in enhancing human values. For example in the arena of environmental studies, the need for coupling local knowledge with the global knowledge on environmental degradation was highlighted by Backstrand (2003) as a necessary path for sustainability, where local "placed-based" knowledge provides alternative perspectives to the global "universal" knowledge. 


\section{Conclusion}

Social science disciplines are confronted with the moral dilemma of fulfilling their duty or role as a science for the understanding of the social world and for seeking to solve practical problems (Embong 2006). This requires adaptation of concepts and theories from universal knowledge (not necessarily Western oriented) and at the same time enacting new knowledge from local world views and wisdoms that are attuned to the local historical and cultural contexts. For social science to remain relevant and practical it has to imbue the normative and natural realm of knowledge.

Instead, social science discourse and knowledge in developing societies appear to be dominated by Western knowledge of a particular kind i.e. Anglo-Saxon tradition. Contestations from within the Western realm as well as developing societies appear to provide a remedy to the contemporary situation, but somewhat at a slow pace and operating in the margins. The nexus of knowledge and power that reins in favor of the Western discourse appears to be numbered, in view of the critique from within and without. With the complementary role of localization of knowledge, one can see the need for a comprehensive globalization of knowledge that is currently skewed in favor of a partial universal knowledge premised on Western epistemologies and ontologies. The alternative (read local) social theorizing provides a milieu for the emergence of new knowledge. The relevance of adapting to local context and the institutional capacity for self-empowerment in localizing knowledge is a necessary path that developing societies should take. With growing flow of people across national boundaries, questions arise as to the complex change that developing countries will encounter and the challenge in adapting and creating new knowledge. The social transformation of the landscape warrants further research into cross-cultural and cosmopolitan studies that can capture the confluence of these diverse multicultural processes.

\section{References}

Agger, B. (2006). Critical Social Theories: An Introduction. London: Paradigm Publishers.

Al Mashat, A. M. (1985). National Security in the Third World. Boulder: Westview Press.

Alagappa, M. (1987). The National Security of Developing Countries: Lessons from Thailand. Dover, MA: Auburn House.

Alatas, S. F. (1995). The sacralization of the social sciences: A critique of an emerging theme in academic discourse. Archives des sciences sociales des religion, 91, 89-111. http://dx.doi.org/10.3406/assr.1995.996

Alatas, S. F. (2001). Alternative discourses in Southeast Asia. Sari, 19, 49-67

Alatas, S. F. (2006). Alternative Discourses in Asian Social Science: Responses to Euro centrism. New Delhi \& Thousand Oaks: Sage Publications.

Alatas, S. H. (1972). The captive mind in development studies. International Social Science Journal, 34(1), 9-25.

Al-Attas, S. N. (1969). Preliminary Statement on a General Theory of the Islamization of the Malay-Indonesian Archipelago. Kuala Lumpur: Dewan Bahasa dan Pustaka.

Anderson, B. (1984). Politics and their Study in Southeast Asia. In R. A. Morse (Ed.), Southeast Asian studies: options for the future. Washington D.C: The Wilson Center.

Ayoob, M. (1986). Regional Security and the Third World. In M. Ayoob (Ed.), Regional Security in the Third World: Case Studies from Southeast Asia and the Middle East. London \& Sydney: Croom Helm.

Ayoob, M. (1995). The Third World Security Predicament: State Making, Regional Conflict, and International System. Boulder \& London: Lynne Reinner Publishers.

Azar, E. E., \& Moon, C. (1988). Introduction. In E. E. Azar, \& C. I. Moon (Eds.), National Security in the Third World: The Management of Internal and External Threats. Aldershot, Hants UK: Edward Elgar Publishing Limited for Center of International Development and Conflict Management, University of Maryland.

Azizan, I. (2012). From Realist Approach to Critical Perspectives: Tracing the Security Studies During and the Post-Cold War era. In K. Abdullah (Ed.), Malaysia's National Security. Bangi: Penerbit UKM (In Malay).

Backstrand, K. (2003). Civic science for sustainability: Reframing the role of experts, policy in makers and citizens. Environmental Governance Global Environmental Politics, 3, 24-41. http://dx.doi.org/10.1162/152638003322757916

Chee, T. S. (1971). Intellectual colonization. Suara Universiti 2, 2, 39-40.

Dean, M. (1999). Governmentality: Power and Rule in Modern Society. London: Sage. 
Embong, A. R. (Ed.). (2006). Peranan dan Orientasi Sains Sosial Malaysia. Bangi: Penerbit UKM.

Fanon, F. N. (1957). Black Skin, White Masks, transl in Charles Lam Markmann (1967 translation). New York: Grove Press.

Foucault, M. (1977). Discipline and Punishment. London: Tavistock.

Foucault, M. (1995). Discipline and Punish: The Birth of the Prison. New York: Vintage.

Foucault, M. (Ed.). (1980). Questions on Geography. In C. Gordon (Ed.), Power/knowledge: selected interviews and other writings 1972-1977. New York: Pantheon.

Gergen, K. J., Lock, A., Gulerce, A., \& Misra, G. (1996). Psychological science in cultural context. American Psychologist, 51, 496-503. http://dx.doi.org/10.1037/0003-066X.51.5.496

Guha, R. (Ed.). (1982). Subaltern Studies I: Writings on South Asian History \& Society. New Delhi: Oxford University Press India.

Husen, B., Christensen, E., Hansen, N. K., Aharon, R., \& Frid-Nielsen, S. (2012, Autumn). Cultural Domination in the Ghanaian Educational System. International Social Science Basic Studies, Third semester. Retrieved January 5, 2013, from http://rudar.ruc.dk/bitstream/1800/9977/1/FINAL\%20Project_Cultural\%20Domination\%20in\%20Ghanaian \%20Education.pdf

Kamarulnizam, A. (2012). Conceptualizing Malaysia's National Security. In K. Abdullah (Ed.), Malaysia’s National Security. Bangi: Penerbit UKM (In Malay).

Kamarulnizam, A., Sivapalan, S., Er, A. C., \& Marlyna, M. (Eds.). (2010). Debates and Issues in Social Science. Bangi: Penerbit UKM.

Kay, C. Y. (1989). Gender, work and ethnicity: ethnography of female factory workers in Singapore. PhD Thesis, Singapore: Department of Sociology, National University of Singapore.

Kincheloe, J. L. (2012). Critical Pedagogy and the Knowledge of the Twenty-First Century. Key Works in Critical Pedagogy, 32, 385-405.

Louw, M. H. H. (1978). Introduction to the National Security Concept. In M. H. H. Louw (Ed.), National Security: A Modern Approach. Pretoria: Institute of Strategic Studies, University of Pretoria, South Africa.

Makinda. (2007). The African Union: Challenges of Globalization, Security and Governance. London: Routledge.

Mason, M. K. (2010). Foucault and His Panopticon. Retrieved May 30, 2011, from http://www.moyak.com/papers/michel-foucault-power.html

Popkewitz, T. S., \& Brennan, M. (1997). Restructuring of social and political theory in education: Foucault and a social epistemology of school practices. Educational Theory, 47, 287-313. http://dx.doi.org/10.1111/j.1741-5446.1997.00287.x

PuruShotam, N. (1993). Caste: woman. Occupation: domestic maid - exploring the realm of foreign full-time workers in Singapore. Working paper presented at the International Colloquium on Migration, Development and Gender in the ASEAN Region, Population Studies Unit, University of Malaya, Kuala Lumpur.

Ravichandran, M., \& Selvadurai, S. (2010). Eastern Worldview of Bioethics. Working Paper Presented at the Eleventh Asian Bioethics Conference /Fifth UNESCO Asia-Pacific School of Ethics Roundtable: Mundialization, Bioethics and Policy. National University Singapore and Asian Bioethics Association.

Said, E. W. (1978). Orientalism. New York: Pantheon Books.

Said, E. W. (1993). Culture and Imperialism. New York: Alfred A. Knopf.

Shamsul. A. B. (2001). Social science in Southeast Asia observed: A Malaysian viewpoint. Inter-Asia Cultural Studies, 2, 177-198. http://dx.doi.org/10.1080/14649370120068513

Sinha, V. (1999). Making Harriet Martineau Visible in Androcentric Sociological Theory. $3^{\text {rd }}$ Asia Pacific Regional Conference of Sociology. Cheju City: Cheju National University.

Sity, D., \& Zarina, O. (2005). Politik dan Keselamatan. Bangi: Penerbit UKM

Tan, A. T. H., \& Boutin, J. D. K. (2001). Non-Traditional Security Issues in Southeast Asia. Singapore: Select Publication. 
Trager, F. N., \& Simonie, F. L. (1973). An Introduction to the Study of National Security. In F. N. Trager, \& P. S. Kronenberg (Eds.), National Security and American Society; Theory, Process, and Policy. Lawrence, KS.: University Press of Kansas.

Waltz, K. (1979). Theory of International Politics. New York: Addison-Wesley Pub. Co.

Wee, V. (1988). Men, women and violence. In A Handbook for Survival. Singapore: SCWO.

Wee, V., Heyzer, N., \& Kwa, A. (1995). Gender, Poverty and Sustainable Development: Towards a Holistic Framework of Understanding and Action. Singapore: Centre for Environment, Gender and Development.

\section{Copyrights}

Copyright for this article is retained by the author(s), with first publication rights granted to the journal.

This is an open-access article distributed under the terms and conditions of the Creative Commons Attribution license (http://creativecommons.org/licenses/by/3.0/). 